Modern Judgements

\title{
HENRY JAMES
}




\section{MODERN JUDGEMENTS}

General Editor: P. N. FURBANK

Dickens A. E. Dyson

Henry James Tony Tanner

Milton Alan Rudrum

Walter Scott D. D. Devlin

Shelley R. B. Woodings

Swift A. Norman Jeffares

IN PREPARATION

Matthew Arnold P. A. W. Collins

Freud F. Cioffi

Marvell $\mathrm{M}$. Wilding

O'Casey Ronald Ayling

Pasternak Donald Davie and Angela Livingstone

Pope Graham Martin

Racine R. C. Knight 


\section{Henry James \\ MODERN JUDGEMENTS}

edited by

TONY TANNER

Macmillan Education 
ISBN 978-0-333-02173-6 ISBN 978-1-349-15259-9 (eBook)

DOI 10.1007/978-1-349-15259-9

Selection and editorial matter (C) Tony Tanner 1968

Softcover reprint of the hardcover 1st edition 1968 978-0-333-08454-o MACMILLAN \& CO LTD

Little Essex Street London wC 2 and also at Bombay Calcutta and Madras

Macmillan South Africa (Publishers) Pty Ltd Johannesburg The Macmillan Company of Australia Pty Ltd Melbourne The Macmillan Company of Canada Ltd Toronto 


\section{Contents}

$\begin{array}{ll}\text { Acknowledgements } & \mathbf{7}\end{array}$

General Editor's Preface 99

Introduction II

Note on the Principles of Selection $\quad 42$

Chronology 44

william troy The Altar of Henry James 46

J. H. RAleigh Henry James: The Poetics of Empiricism 52

MAURICE BeEbe The Turned Back of Henry James 7I

viola hoprins Visual Art Devices and Parallels in the Fiction of Henry James $\quad 89$

william J. maseychik Points of Departure from The American II6

J. A. WARD The Europeans and the Structure of Comedy

tony tanner The Fearful Self: Henry James's The Portrait of a Lady

william McMurray Pragmatic Realism in The Bostonians 160

DaNiel Lerner and oscar Cargill Henry James at the Grecian Urn I66

J. M. LUeCKe The Princess Casamassima: Hyacinth's Fallible Consciousness

Lyall H. POWers James's The Tragic Muse-Ave Atque Vale

ROBERT C. MCLEAN The Subjective Adventure of Fleda Vetch 
James w. gargano What Maisie Knew: The Evolution of a 'Moral Sense'

H. K. GIRLIN G 'Wonder' and 'Beauty' in The Awkward Age

WALTER ISLE The Romantic and the Real: Henry James's The Sacred Fount 245

JEAN KIMBALL The Abyss and The Wings of the Dove: The Image as a Revelation 266

IAN WATt The First Paragraph of The Ambassadors: an explication

William M. Gibson Metaphor in the Plot of The Ambassadors

WALTER WRIGH Taggie Verver: Neither Saint nor Witch

NAOMI LEBOWITZ Magic and Metamorphosis in The Golden Bowl

Select Bibliography

Notes on Contributors

Index 


\section{Acknowledgements}

William Troy, 'The Altar of Henry James', from The New Republic, Is (c) Harrison-Blaine of New Jersey Inc I943); John Henry Raleigh, 'Henry James: The Poetics of Empiricism', from Publications of the Modern Language Association of America, lxvi (195I) (The Modern Language Association of America); Maurice Beebe, 'The Turned Back of Henry James', from South Atlantic Quarterly, 1954 (Duke University Press); Viola Hopkins, "Visual Art Devices and Parallels in the Fiction of Henry James', from Publications of the Modern Language Association of America, lxxvi (196I) (The Modern Language Association of America); William J. Maseychik, 'Points of Departure from The American'; 'James's The Europeans and the Structure of Comedy', from Nineteenthcentury Fiction, pp. I-I6 (Dr J. A. Ward and The Regents of the University of California; (c) The Regents I964); Tony Tanner, 'The Fearful Self: Henry James's The Portrait of a Lady', from Critical Quarterly, 1965; 'Pragmatic Realism in The Bostonians', from Nineteenth-century Fiction, pp. 339-44 (Dr William McMurray and The Regents of the University of California; (c) The Regents 1962); Daniel Lerner and Oscar Cargill, 'Henry James at the Grecian Urn', from Publications of the Modern Language Association of America, lxvi (195I) (The Modern Language Association of America); Sister Jane Marie Luecke, 'The Princess Casamassima: Hyacinth's Fallible Consciousness', from Modern Philology, pp. 274-80 (The University of Chicago Press); Lyall H. Powers, 'James's The Tragic Muse - Ave Atque Vale', from Publications of the Modern Language Association of America, lxxiii (1958) (The Modern Language Association of America); Robert C. MacLean, 'The Subjective Adventure of Fleda Vetch', from American Literature, I964 (Duke University Press); 'What Maisie Knew: The Evolution of a "Moral Sense" ', from Nineteenth-century Fiction, pp. 33-46 (Dr James Gargano and The Regents of the University of California; (c) The Regents I96I); H. K. Girling, "Wonder" and "Beauty" in The Awkward Age', from 
Essays in Criticism, I958 (The Editor); Walter Isle, 'The Sacred Fount', from Experiments in Form: Henry James's Novels, 1896-1901 (Harvard University Press; (c) The President and Fellows of Harvard College I968); 'The Abyss and The Wings of the Dove: The Image as a Revelation', from Nineteenth-century Fiction, pp. 28I-300 (Mrs Jack F. Kimball and The Regents of the University of California; (C) The Regents I956); Ian Watt, 'The First Paragraph of The Ambassadors: An Explication', from Essays in Criticism, 1960 (The Editor); William M. Gibson, 'Metaphor in the Plot of The Ambassadors', from The New England Quarterly (Sept. 195I); 'Maggie Verver: Neither Saint nor Witch', from Nineteenth-century Fiction, pp. 59-7I (Dr Walter Wright and The Regents of the University of California; (C) The Regents 1957); 'Magic and Metamorphosis in The Golden Bowl', from The Sewanee Review, lxxiii I (Winter 1956) (Mrs Naomi Lebowitz and The University of the South). 


\section{General Editor's Preface}

LiterARY criticism has only recently come of age as an academic discipline, and the intellectual activity that, a hundred years ago, went into theological discussion, now finds its most natural outlet in the critical essay. Amid a good deal that is dull or silly or pretentious, every year now produces a crop of critical essays which are brilliant and profound not only as contributions to the understanding of a particular author, but also as statements of an original way of looking at literature and the world. Hence it often seems that the most useful undertaking for an academic publisher might be, not so much to commission new books of literary criticism or scholarship, as to make the best of what exists easily available. This at least is the purpose of the present series of anthologies, each of which is devoted to a single major writer.

The guiding principle of selection is to assemble the best modern criticism - broadly speaking, that of the last twenty or thirty years and to include historic and classic essays, however famous, only when they are still influential and represent the best statements of their particular point of view. It will, however, be one of the functions of each editor's Introduction to sketch in the earlier history of criticism in regard to the author concerned.

Each volume will attempt to strike a balance between general essays and ones on specialised aspects, or particular works, of the writer in question. And though in many instances the bulk of the articles will come from British and American sources, certain of the volumes will draw heavily on material in other European languages - most of it being translated for the first time.

P. N. FurbaNK 


\section{Introduction}

When Henry James was composing his prefaces for the New York Edition of his works (published 1907-9), he wrote about them to William Dean Howells (I7 August 1908): 'They are, in general, a sort of plea for Criticism, for Discrimination, for Appreciation on other than infantile lines - as against the so almost universal AngloSaxon absence of these things which tends so, in our general trade, it seems to me, to break the heart.' These prefaces not only remain one of the richest sources of insight into James's intentions in his novels; they elevated discussion of the whole genre of the novel to a height of aesthetic and moral seriousness which had never previously been attained, and which established the point of departure for all subsequent exploration and criticism of 'the novel'. R. P. Blackmur called them 'the most eloquent and original piece of literary criticism in existence': certainly if 'Discrimination' and 'Appreciation' are no longer so entirely absent from the English-speaking world one of the reasons must be the attention which has been paid to the profound critical explications James wrote about his own creations. 'To criticise', he wrote in one of the prefaces, "is to appreciate, to appropriate, to take intellectual possession, to establish in fine a relation with the criticised thing and make it one's own.' My intention here is to give a brief account of how James's novels have been appreciated and appropriated - or not been so - from the time when he was lamenting the 'infantile' critical faculties of his contemporaries to the present day, when every year brings forth around forty articles, three or four books, and an unknown number of dissertations on his work, much of this critical writing being of a high degree of sophistication.

How was James's work received by his contemporaries? In general we can say that while his books were not received with sufficient popular enthusiasm to ensure him substantial financial success (not a 
trivial matter for James, contrary to some popular notions of his unearned affluence), and while very few of his defenders showed any very deep understanding of what he was doing, nevertheless he was never really neglected, indeed he was almost immediately recognised as a major writer of some sort, and within his own lifetime he received the genuinely appreciative acclaim of three very different but very important fellow novelists - William Dean Howells, Joseph Conrad, and Ford Madox Ford. One thing is indisputable, however: a reading of the reviews of the time, even the most enthusiastic, reveals a current critical vocabulary of disabling vagueness and crude imprecision. And, inevitably, right from the start, James's attitude towards America and his apparent preference for Europe continually diverted attention from his achievements as a novelist.

An example of the most balanced sort of reaction to the young Henry James may be found in an essay by Thomas Wentworth Higginson, written in I879. ${ }^{\mathrm{I}}$ He praises James, not very helpfully, for his 'delicacy, epigram, quickness of touch, penetration', but continually strays back to the question of James's attitude to America.

$\mathrm{Mr}$ James's life has been so far transatlantic that one hardly knows whether he would wish to be counted as an American writer, after all. ... When he says, for instance, that a monarchical society is 'more available for the novelists than any other', he shows that he does not quite appreciate the strong point of republicanism, in that it develops real individuals in proportion as it diminishes conventional distinction.

He approves of those stories which, like Daisy Miller (I878), 'have been written with distinct purpose and convey lessons', and he admits to the power of some of James's work. He faults him for his handling of America, but 'when he draws Americans in Europe he is at home'.

There is no real hostility there, and indeed there was at the time a readiness to admire James as Hawthorne's successor.

It is fair to remember that The Portrait of a Lady (188I) was greeted as an important literary event and gave rise to much serious discussion. But even discounting the more parochial and irrelevant reviews (such as those which fastened on the absence of religious sentiments in the characters), one is bound to remark on the ineptness of much of the critical discussion of the novel. 'There is no heart in it; there is plenty of brightness, acuteness, wit and good writing; but not enough to

I In Literary World, x (22 Nov. 1879). 
redeem it from the effect of literary Pyrrhonism.' Thus one reviewer dealt with the novel; while the more enthusiastic asserted their liking without offering any very concrete grounds for it. It is worth noting that at this time James was identified by one critic as a product of the 'modern or scientific methods of novel-writing', that he was a realist and a materialist who discounted whatever was spiritual and transcendental. From the start James had been singled out as an unusually deft 'analyst' of human thoughts and feelings, but that word has a very ambiguous status in nineteenth-century discussion of literature. 'Analysis' was felt to be potentially hostile to all that was fine and spiritual in man; it denied the soul and might well destroy the heart. In general, analytical writing was unfeeling and 'cold' - an epithet that was attached to James's work again and again. The majority of late-nineteenth-century readers still preferred 'warm' novelists, such as Dickens, Scott and Thackeray, who seemed so reassuringly simple, so full of heart, so happily above meddling with the devious and problematical motions of the inner world. Before James could gain proper recognition for his work there had to be a change in the prevailing attitude towards the scope and technique of the novel itself. William Dean Howells, acutely aware as ever of what was happening in the literature of his own day, could see that James was really developing a new kind of novel, and he said as much in a forthright article ${ }^{\mathrm{I}}$ which earned him some angry attacks from English critics. For Howells maintained that James was the 'chief exemplar of the new art of fiction', a fiction which, Howells maintained, was both more refined and more artistic than that of writers such as Dickens and Thackeray. Howells praised James for his scrupulous analysis of motive and intelligently invoked George Eliot as an important contemporary who was also developing a more analytical type of fiction. It was also in this article that Howells praised James for inventing the 'international novel', a felicitous phrase which is still in currency, though it sometimes obscures those matters in James's work which transcend the fruitful fascination of national differences.

For a few years James remained fairly consistently popular, but the publication of The Bostonians (I886) provoked a barrage of crude hostility. One typical example: 'Mr James may nowadays be looked upon as the head of a certain college of savants, a man delighting in writing what to the majority of flesh-and-blood men and women

I 'Mr Henry James, Jr, and His Critics', in Literary World, XIII (I4 Jan. I882). 
has no excuse for being so praised, and books that grow more and more arid and dull. This long, prosy, carefully written novel was not worth writing and is unreadable.' Thus a novel which many readers today enjoy as being remarkably free of the idiosyncrasies and complexities which make James's later work unappealing to some, paradoxically all but ruined James's reputation as a novelist in his own time. However The Princess Casamassima (I886) was met with more approval and appreciation, with Howells as usual writing the most sympathetic and enlightened review and calling it incomparably the greatest novel of the year in our language'. Even more gratifying was the reception accorded to The Tragic Muse (I 890): it was reviewed extensively and favourably and was one of James's most successful novels. One review, for example, said the novel was 'by far the most brilliant and faithful representation of the successful actress' ever achieved in English fiction. Here we meet a second paradox, because today this fine novel receives less critical attention than any of James's novels (going through the critical journals of the last fifteen years indeed even further back - I found only one serious article devoted to the novel).

After The Spoils of Poynton (1897), which was also fairly successful, James's reputation began to decline again. Reviewers often paid lipservice to his 'brilliance' and 'subtlety', but as often they revealed their bewilderment and boredom. If they applauded the virtuosity of giving us the story of What Maisie Knew (I897) from the point of view of the child, they would at the same time condemn the style of the book as tortuous, incoherent and vague. Although the keen social observations in The Awkward Age (1899) were praised, the characters were attacked as being bloodless or over-analysed to the point of tedium. (One critic, rather wittily, expressed relief that James 'had arrived at the point of intellectual remoteness from the flesh' because to think of Mrs Brookenham and her crowd, 'those frankly inquiring minds and untrammelled spirits' united with bodies, would be to picture a rotten bunch.) Only one critic noticed that James was trying a radically new technique here-i.e. reducing the privileges of the omniscient author to a minimum and allowing his characters to reveal themselves through conversation. Since this was the first time James had deliberately tried to adapt the technique of drama to the novel, the perceptiveness of this lone critic (in the Nation) is much to be praised. The reception of The Sacred Fount (1901) marks the second really 
low point in James's reputation during his own lifetime: 'morbid analysis', 'brilliantly stupid', 'Mr James was intent on making nothing out of nothing' - these are representative comments. Quite a number of modern readers would not consider these to be so very unfair, but here I want to point out a third paradox in the history of James's reputation. This strange little novel (excluded from the New York Edition by James) has received an increasing amount of attention in recent years - perhaps partly as a result of Edmund Wilson's suggestion that if we could get at the hidden secret of this book we might have a major key to all of James's work. Certainly it is open to a diversity of interpretation, which has made it peculiarly congenial to modern critics. The Wings of the Dove (1902) did not do much to restore James's reputation. Many critics were now referring to James's 'latest manner', with the usual implication that it was a manner for the delectation of the very few. Complaints that his late work is too remote from real life, that he cannot make any direct moral judgements on his characters, were common then as they still are now. Some put it crudely: James 'has now successfully lost himself in the ultimate azure of himself'; others more gently: James 'frequently retires so deeply within himself that the more he labors to express his meaning, the more involved and incommunicable he becomes'. In a good-humoured but derisive article $^{\mathrm{I}}$ Frank Moore Colby made a comment on the book which became quite well known. 'Through page after page he surveys a mind as a sick man looks at his counterpane, busy with little ridges and grooves and undulations. There are chapters like wonderful games of solitaire, broken by no human sound save his own chuckle when he takes some mysterious trick or makes a move that he says is "beautiful".' (It was also Colby who made the dry - yet inaccurate comment that in James's books 'nobody sins because nobody has anything to sin with'.)

Once again it was Howells who insisted that James's recent books were 'incomparable'. ${ }^{2}$ 'It does not matter . . . how the people talk - or in what labyrinthine parentheses they let their unarriving language wander. They strongly and vividly exist, and they construct not a drama, perhaps, but a world, floating indeed in an obscure where it seems to have its solitary orbit, but to be as solidly palpable as any of the planets of the more familiar systems.' At a time when people were

I 'In Darkest James', in Bookman, Nov. 1902.

2 'Mr Henry James's Later Work', in North American, ClXxvi (Jan. I903). 
starting to ignore James, Howells addressed them firmly: 'here you have the work of a great psychologist, who has the imagination of a poet, the wit of a keen humorist, the conscience of an impeccable moralist, the temperament of a philosopher, and the wisdom of a rarely experienced witness of the world'. This important article was one of two main defences of James written around this time: the other was by Cornelia Pratt, ${ }^{\mathrm{I}}$ who discerned in James's whole work 'the spectacle of a cumulative artistic life'. She admires and defends his later style, but once again the sheer inadequacies of her vocabulary prevent her from saying anything really very helpful about the deeper meanings and intentions of the books.

Oddly enough, since modern readers still tend to find it quite as difficult as The Wings of the Dove, it was The Ambassadors (1903) which restored James's reputation, and restored it rather sensationally at that. 'The real thing once more!' said the Literary World; others greeted it as a masterpiece, 'a work of noble literature', and so on. The style was not now criticised, and the plot was praised. Some critics manifested a general grasp of James's subject. 'He has been the sensitive register of the results of the influence of the older society on the crudities, the rawness, or, at its best, the inexperience of a new society. ... He has recorded the modification or surrender of the provincial to the Old World spirit. No other report of this phase of recent life has been at once so searching and so subtle as The Ambassadors.' But here again we see how very little even the admiring critics were able to say. 'He makes a plot out of so very little, and behold it is so much.' It must certainly have been preferable for James to see his book referred to as 'enchanting' than to have it dismissed as incomprehensible, but he must have wondered at times just what even his most ardent admirers were getting out of his books. And by this time his admirers were becoming aware of themselves as a select few, sadly (or perhaps smugly) recognising that James could not be universal in his appeal. 'A man too great to be ignored', said the American critic Claude Bragdon of James, but he went on, '[and] too ignored to be great, for his appeal is, and must ever be . . . to a "parlor audience".' It was this same critic who praised James as the most modern of modern novelists because he depicted human nature as it failed or flourished in highly organised society, distorted, refined or sublimated by forms of civilisation. James's subjects, 'the voiceless little tragedies of the

I 'The Evolution of Henry James', in Critic, xxiv (April 1899). 
soul: the dilemmas of the super-refined, the intellectual enthusiasms of young men, the abortive love of spinsters', were, he said, more relevant to modern life than the situations to be found in conventional romances. But such comparatively enlightened attitudes to James's work were still counterbalanced by complaints that it was the product of 'the analytic, not the inspired'. Nevertheless it is true to say that The Ambassadors was greeted with more respect than almost any other of James's novels. Interestingly, this is the one marked coincidence between modern taste and that of James's contemporaries. For in recent years I would say that The Ambassadors has been more written about than any other of James's works.

After The Ambassadors James's reputation remained high for some time, and interest and enthusiasm among American critics was aroused by his proposed return visit to his homeland in 1904. An extremely fair essay by Herbert Croly published in that year is worth singling out: 'Henry James and His Countrymen'. reasons for finding Europe a more fruitful ground for his art and denies the trivial objections that he has been unpatriotic: 'one can easily understand that an artist who places such a high value upon a large and disinterested intellectual outlook may find it desirable to exalt his art at the expense of his patriotism'. He notes - without outrage - James's preoccupation with a class of people who are for the most part 'economic parasites' and describes the sort of situation which James likes to work on. 'It is a subtle, exciting, and finished social situation, which he isolates, analyzes, interprets, and composes, with his eyes fastened exclusively upon the psychological aesthetics of the people and the social aesthetics of their attitudes toward one another.' $\mathrm{He}$ is clearly aware of James's imaginative skill - for instance, he makes the perceptive observation that James uses 'houses and rooms which illuminate and intensify' the characters. 'He has given, indeed, a new value in the art of novel writing to domestic properties and scenery.' But he leaves it at that, whereas a modern critic would make that his point of departure and try to show exactly how James makes architectural setting contribute to the overall meaning of his work. But he also puts James in a class outside the mainstream of the American novel. 'Whatever else this novel possesses, it must possess energy, excitement, momentum, and purpose.' That is, he equates the true American novel with the novel of external action. "While [James] has 
renounced any attempt to deal with action, achievement, it is just such action and achievement by which [his contemporary fellow countrymen] are fascinated and engrossed.' We _can see here signs of that division of American writers into 'palefaces' and 'redskins' which Philip Rahv later discussed in a celebrated essay. ${ }^{I}$ But the most important aspect of Croly's essay is that he sees James as representing a type of artistic integrity which American writers will have to emulate. 'The penalty which $\mathrm{Mr}$ James pays for his expatriation, for his exclusive and consistent loyalty to his personal faith and vision, is just the penalty of being wholly separated from this main stream of American literary fulfillment.' But, he goes on, if the 'consummation' of American literature is to be reached, 'it will be reached only by the acquisition on the part of his literary fellow countrymen of an artistic and intellectual integrity analogous to that of Henry James'.

The Golden Bowl (1904) sold unusually well, but it received mainly adverse criticism, couched in the by now customary, imprecise emotive phrases. 'It is thin and bloodless .... it is art without the dimmest adumbration of a soul.' Some comments were more specific: 'we find, standing for subtlety, a kind of restless, finicking inquisitiveness, a flutter of aimless conjecture'. As against this general relapse into the old impatience with James, Claude Bragdon's review is genuinely sympathetic and understanding.

Those who lament the forsaking by $\mathrm{Mr}$ James of his earlier themes and abandonment of his more direct and objective manner, perhaps betray the limit of their own interests and perceptions. Like all men of original genius arrived at maturity, the outward aspects of the world no longer interest him. Little by little he has come to look for and present the reality behind the seeming.

But such isolated sensitive reviews could do little to stop the general trend towards a state of general indifference towards James's work. People became apathetic about him. The American Scene (1907) was counted disappointing, and the New York Edition was neglected, even ignored.

The autobiographical volumes, $A$ Small Boy and Others (I913) and Notes of $a$ Son and Brother (I9I4), revived interest in James to some degree, but 'although at the time of his death in I9r6 his reputation was secure, he was a somewhat neglected and not fully appreciated

I 'Paleface and Redskin', in Image and Idea (New York, 1949). 
writer'. I take that last comment from a published dissertation by Richard Foley entitled Criticism in American Periodicals of the Works of Henry James from 1866 to 1916 (Washington, 1944). Mr Foley's research has been copious, and I am indebted to it for some of the information contained in the preceding pages. One of his conclusions emphasises the general point I have been wanting to make about the impressionistically vague, non-analytic tenor of most of the contemporary criticism.

Surprisingly few intelligent observations were made upon James's own explanation of technical problems such as foreshortening, choice of narrator, revealing center, use of dialogue, and the like in the Prefaces. Granted the fact that no major fiction appeared after the publication of the New York Edition, it is still difficult to account for the dearth of incisive reviews of his last stories or any significant appraisals of his work in general after he had set forth his theory of fiction.

In the years between the turn of the century and the First World War people were not much interested in what James was trying to do with the novel; it was worth remembering that it was during this period that Conrad's works sold so poorly and Proust had his great work turned down by a leading French publishing house. A new vision of man, a shift in focus on his inner and outer world, necessitates the development of new techniques, in fiction as in any other art. The general public and, indeed, most of the critics prior to I9I4 were unprepared for a shift in vision, and so, for the most part, were mainly bewildered by the innovations in technique which confronted them.

But there was some other criticism of James's work written during his lifetime which should be noted. In I905 Joseph Conrad wrote a short appreciation ${ }^{\mathrm{I}}$ which included at least one phrase which all subsequent criticism of James has scarcely bettered when it comes to summing up James's particular province. 'Mr Henry James is the historian of fine consciences' is Conrad's memorable sentence; and he develops his meaning.

The range of a fine conscience covers more good and evil than the range of a conscience which may be called, roughly, not fine; a conscience less troubled by the nice discriminations of conduct. A fine conscience is more concerned with essentials; its triumphs are more perfect, if less profitable,

I 'Henry James: an appreciation', in North American Review, CLxxx (Jan. I905) 102-8; reprinted in Notes on Life and Letters (London and New York, 1921). 
in a worldly sense. There is, in short, more truth in its working for a historian to detect and to show. It is a thing of infinite complication and suggestion. None of these escapes the art of Mr Henry James.

Also in I905 Elisabeth Luther Cary published what is to the best of my knowledge the first book-length study of James's work. ${ }^{I}$ It is not a deeply probing book, but it contains many felicities of general appreciation. She says that James combines 'tactile values with the greatest possible amount of spiritual truth. In other words, his technical curiosity, his ability to represent life pictorially by a multiplicity of fine observations, runs hand in hand with a curiosity far more unusual and far more difficult to satisfy, a curiosity as to moral states and responsible affections.' She makes lucid comments on his characters and ideas, and on such aspects of his work as the use he makes of juxtaposing the present with the past which she describes as his habit 'of using the vanished scene as a touchstone for the one before us, of holding up his brilliant picture against the soft, thick background of accumulated associations to try the value of its modern tone'. But repeatedly she returns to her one basic general perception about his work: "his strength was chiefly to lie in combining close observation of the surface of life with indefatigable exploration of the recondite truths of the spirit'.

Another short encomium which is certainly worth mentioning occurs in one of Max Beerbohm's theatre-pieces, written in $1909 .{ }^{2} \mathrm{He}$ describes James as having an outlook 'full of reverence for noble things and horror of things ignoble' and says that his characters are distinguished by 'the passion of conscience, a sort of lyrical conscience, conscience raised to the pitch of ecstasy'. And although he later wrote a parody of James's late style - 'The Mote in the Middle Distance' (I9I2) 3 - which failed to amuse James (a parody, incidentally, a good deal subtler and gentler than H. G. Wells's crude satire of James in Boon in I9I5), he here reveals a genuine sensitivity to 'the later James' - 'the James who has patiently evolved a method of fiction entirely new, entirely his own, a method that will probably perish with him, since none but he, one thinks, could handle it; that amazing method by which a novel competes not with other novels, but with

I The Novels of Henry James (New York, I905).

2 'Mr Henry James's Play'; reprinted in Around Theatres (London and New York, 1953).

3 In $A$ Christmas Garland (1912, new ed., r950). 
life itself; making people known to us as we grow to know them in real life, by hints, by glimpses, here a little and there a little, leaving us always guessing and wondering, till, in the fullness of time, all these scraps of revelation gradually resolve themselves into one large and luminous whole, just as in real life'.

I think Henry James: A Critical Study (1913) by Ford Madox Hueffer (later Ford) must be counted as the first really important book on James. It is marked by the mannerisms which many people associate with Ford's writing - the exaggerated statement, the expansive gesture, the half-reliable anecdote - but, despite the idiosyncratic informality of his style, Ford was able to show exactly how James's work differed from the conventional English novel; how it should be seen in conjunction with certain aspects of continental fiction; and just exactly what was important about James's formal and technical innovations. Ford must be one of the first critics to quote extensively from James's critical prefaces, and that fact alone suggests that he really understood what James was doing. He starts his book by declaring emphatically that 'I regard the works of Mr Henry James as those most worthy of attention by the critics' and quickly went on to single out James as greater than all his contemporaries 'for analysis'. The word is now wholly approbative - a fact which reminds us that Ford was one of the earliest and most tireless champions of the whole modern movement in literature. In dealing with James's 'Subjects' Ford applauds him as 'the historian of one, of two, and possibly of three or more, civilisations' and insists that 'he, more than anybody, has observed human society as it now is, and more than anybody has faithfully rendered his observations for us'. As a general proposition he says that the modern novel (this is I9I3) was notable for making 'an attempt at shadowing the real problems of the contact of individual with individual', and he praises James for being 'earliest in the field'. The last section of his book is called 'Methods', and while it contains nothing so rigorously analytical as more recent criticism can offer, it reveals a firm grasp of just what was new and important in James's method, just why his books give us the impression of 'vibrating reality'. 'I think the word "vibrating" exactly expresses it; the sensation is due to the fact that the mind passes, as it does in real life, perpetually backwards and forwards between the apparent aspect of things and the essentials of life.' Ford, who made it his life-work to try to inculcate some sense of 'form', some consciousness of artistic technique into the English, deserves high 
praise for holding up Henry James as an example of a major artist at a time when most people were dismissing him as a long-winded bore.

Looking upon the immense range of the books written by this author, upon the immensity of the scrupulous labours, upon the fineness of the mind, the nobility of the character, the highness of the hope, the greatness of the quest, the felicity of the genius and the truth that is at once beauty and more than beauty - of this I am certain, that such immortality as mankind has to bestow . . . will rest upon the author of Daisy Miller. It will rest also with the author of The Golden Bowl.

Ford was right, of course, as were Conrad and Howells and one or two more rare intelligences. One can only hope that this minimum of true recognition and appreciation was some consolation for Henry James while he was alive. All the same, it would not be much of an exaggeration to say that at the time of his death all the serious detailed critical work on his novels remained yet to be done.

IT would be misleading to pretend that the situation changed with dramatic suddenness after James's death. Indeed, five years elapsed before Percy Lubbock published his crucial book The Craft of Fiction (192I), but during that period there was some important criticism worth mentioning. In 1917, for instance, Stuart Sherman published an important article called 'The Aesthetic Idealism of Henry James', in which he made a retrospective survey of James criticism and tried to sum up "what Henry James was "trying for" '.

Criticism's favorite epithets for him hitherto have been 'cold', 'analytical', 'scientific', 'passionless', 'pitiless' historian of the manners of a futile society. That view of him is doomed to disappear before the closer scrutiny which he demanded and which he deserves. He is not an historian of manners; he is a trenchant idealistic critic of life from the aesthetic point of view.

Sherman willingly admits that 'he has insulted all the popular gods of democratic society' in order to insist that James owed his allegiance to something more important. 'The thing which he, as the high priest solemnly ministering before the high altar, implored someone to

I In Nation, crv (5 April 1917) 393-9; reprinted in On Contemporary Literature (New York, 1917; London, 1923). 
observe and to declare is that he adored beauty and absolutely nothing else in the world.' This stress on 'the exclusiveness of his consecration to beauty', this insistence that James judged everything on the level 'of the aesthetic consciousness' tends to put James in a rather decadent, fin-de-siècle light. Nonetheless Sherman is clearly quite a sensitive critic, and he says some things well. 'What he offers us, as he repeatedly suggests, is a thousand-fold better than life; it is an escape from life. It is an escape from the undesigned into the designed, from chaos into order, from the undiscriminated into the finely assorted, from the languor of the irrelevant to the intensity of the pertinent.' And clearly Sherman is an enthusiastic reader of James's prefaces, 'which more illuminate the fine art of fiction than anything else - one is tempted to say, than everything else - on the subject'. But remarks like the following could later be damaging to James: 'James is like Pater in his aversion from the world, his dedication to art, his celibacy, his personal decorum and dignity, his high aesthetic seriousness, his Epicurean relish in receiving and reporting the multiplicity and intensity of his impressions, and in the exacting closeness of his style.' Walter Pater! It is a surprising, but not wholly foolish, comparison - though very misleading as a way of getting at the particular greatness of James's achievement. But the time was not so very far off when the impinging pressure of economic and political problems would make any artist who ignored these ugly realities appear at best irrelevant, at worst suspect or contemptible. Sherman's picture of James as an exquisite devotee of 'the beautiful' was one which could only do him harm in the I930s, when it seemed all but inhuman to lack a social conscience.

But the death of Henry James prompted brief appreciations, in 1918 , from two young American expatriate writers who were to be major influences in the modern literary movement-Ezra Pound and T. S. Eliot. Pound used the occasion to scorn the Americans for not even realising what they had lost ${ }^{\mathrm{I}}$ - part of his running battle with the philistinism of America. But at the same time he made some penetrating remarks about the essential achievement of James. He sees him as a man who devoted all his energy 'to bring in America on the side of civilisation' and dismisses all hostile criticisms of James's style as petty.

What I have not heard is any word of the major James, of the hater of

I 'A Brief Note', in Little Review: Henry James Number, v (Aug. 1918). 
tyranny; book after early book against oppression, against all the sordid petty personal crushing oppression, the domination of modern life. . . . What he fights is 'influence', the impinging of family pressure, the impinging of one personality on another; all of them in highest degree damn'd, loathsome, and detestable.

Pound sees James as one of the first great American writers whose genius was on the side of 'human liberty, personal liberty, the rights of the individual against all sorts of intangible bondage! The passion of it, the continual passion of it in this man who, fools said, didn't "feel". And he claims for James the sort of seriousness which the attitude of people like Sherman tended to overlook. 'His art was great art as opposed to over-elaborate or over-refined art by virtue of the major conflicts which he portrays.' Pound's piece was short, but it was more cogent and penetrating than most of the work written on James up to that date.

T. S. Eliot adopted a more aloof oracular tone in praising James, permitting himself, however, the bitter irony of remarking that both England and America should have been more relieved than they were at the news of James's death: he was such a brilliant critic of both. It was in this essay that Eliot made the famous statement: 'James's critical genius comes out most tellingly in his mastery over, his baffling escape from, Ideas; a mastery and an escape which are perhaps the last resort of a superior intelligence. $\mathrm{He}$ had a mind so fine that no idea could violate it.' Eliot's words here are chosen with great care and the exactness of this short statement points to an aspect of James's genius which had never been so clearly defined before. Eliot extended his praise by saying of James: 'He is the most intelligent man of his generation.'

In the same year, 1918, Joseph Warren Beach published a notable book on The Method of Henry James, which was full of considered insights and balanced appraisals. Beach stressed that James was less concerned to tell a simple 'story' than 'to give us instead the subjective accompaniment of the story. His "exquisite scheme" was to confine himself as nearly as possible to the "inward life" of his characters, and yet to make it as "exciting" for his readers as it was for the author, as exciting-were that possible - as it was for the characters themselves.' He insists that although the overriding preoccupation in his books seems to be with 'good taste' and 'refinement', in fact they are

I 'The Hawthorne Aspect', in Little Review: Henry James Number, v (Aug. I918). 
profoundly moral. James's 'exclusive concern with the inward life' explains 'the dominance of ethical considerations'. And Beach makes some attempts to show how this preoccupation with the inner life affected James's techniques and the kind of characters he chose to scrutinise. 'For the characters of James the faculty of supreme importance is the intelligence, or insight, the faculty of perceiving "values" beyond those utilities upon which everyone agrees.'

The year 1918 was certainly an important one for James criticism, and one can see that for a period after the terrible international convulsions of the war James came to represent for some people the supremely civilised intelligence: they saw his work as being opposed to barbarism, tyranny and the crassness of merely utilitarian values. In another brief note on James, written in I924, Eliot stressed, in his own way, James's dedication to an ideal of peaceful, reasonable civilisation. ${ }^{\mathrm{I}}$

He was possessed by the vision of an ideal society. . . J James did not provide us with 'ideas', but with another world of thought and feeling. For such a world some have gone to Dostoievsky, some to James; and I am inclined to think that the spirit of James, so much less violent, with so much more reasonableness and so much more resignation than that of the Russian, is no less profound, and is more useful, more applicable, for our future.

At the same time essays were appearing from other writers, praising James's fictional techniques - Edith Wharton and Virginia Woolf both wrote respectful articles in the early I920s.

Percy Lubbock's famous book The Craft of Fiction (I92I) is not only remarkable for the masterly criticism and appreciation of James contained in it; it was, as Mark Schorer once wrote, 'probably the first that tried to treat fiction as an art'. Other writers of the period made respectful general comments on James's fine technique, but Lubbock was the first to examine the actual operational details of technique. He asked 'how' questions: how is a novel made, how does it work? The following quotation should be seen as a milestone in novel criticism.

Let us very carefully follow the methods of the novelists whose effects are incontestable, noticing exactly the manner in which the scenes and figures in their books are presented. . . . Our criticism has been oddly

I 'A Prediction in Regard to Three English Authors', in Vanity Fair (Feb. 1924). 
incurious in the matter, considering what the dominion of the novel has been for a hundred and fifty years. The refinements of the art of fiction have been accepted without question, or at most have been classified roughly and summarily - as is proved by the singular poverty of our critical vocabulary, as soon as we pass beyond the simplest and plainest effects. The expressions and the phrases at our disposal bear no defined, delimited meanings ... we still suffer from a kind of shyness in the presence of a novel ... we are haunted by a sense that a novel is a piece of life, and that to take it to pieces would be to destroy it . . . it is not a piece of life, it is a piece of art like another; and the fact that it is an ideal shape, with no existence in space, only to be spoken of in figures and metaphors, makes it all the more important that in our thought it should be protected by no romantic scruple.

Lubbock has an intimate knowledge of James's ideas about fiction he edited the later volumes of the New York Edition and then his letters - and his sensitive grasp of James's sense of the craft of fiction enabled him to write, not only a seminal work for all subsequent novel criticism, but some especially brilliant appreciation of James's own techniques. In a really outstanding section on The Ambassadors he scrutinises exactly what that technique is and how it works. With this section we enter - in the most distinguished manner - the modern era of James appreciation. I will run some quotations together to give some sense of the great step forward his work represents.

The world of silent thought is thrown open, and instead of telling the reader what happened there, the novelist uses the look and behaviour of thought as the vehicle by which the story is rendered . . . suppose that instead of a man upon the stage, concealing and betraying his thought, we watch the thought itself, the hidden thing, as its twists to and fro in his brain - watch it without any other aid to understanding but such as its own manner of bearing might supply. The novelist, more free than the playwright, could of course tell us, if he chose, what lurks behind this agitated spirit; he could step forward and explain the restless appearance of the man's thought. But if he prefers the dramatic way, admittedly the more effective, there is nothing to prevent him from taking it. The man's thought, in its turn, can be made to reveal its own inwardness.

Let us see how this plan is pursued in The Ambassadors. . . . This is a story which must obviously be told from Strether's point of view, in the first place. The change in his purpose is due to a change in his vision, and the long slow process could not be followed unless his vision were shared by the reader. . . . Only the brain behind his eyes can be aware of the colour of his experience, as it passes through its innumerable gradations; 
and all understanding of his case depends upon seeing these. . . . Neither as an action set before the reader without interpretation from within, nor yet as an action pictured for the reader by some onlooker in the book, can this story possibly be told. . . .

But though in The Ambassadors the point of view is primarily Strether's, and though it appears to be his throughout the book, there is in fact an insidious shifting of it, so artfully contrived that the reader may arrive at the end without suspecting the trick. The reader, all unawares, is placed in a better position for an understanding of Strether's history, better than the position of Strether himself.

Lubbock describes exactly how this complex effect is gained without the author intruding on the reader's perceptions and inferences. He points out that James is showing us a man who is 'slowly turning upon himself and looking in another direction'.

To announce the fact, with a tabulation of his reasons, would be the historic, retrospective, undramatic way of dealing with the matter. To bring his mind into view at the different moments, one after another, when it is brushed by new experience - to make a little scene of it, without breaking into hidden depths where the change of purpose is proceeding to multiply these glimpses until the silent change is apparent, though no word has actually been said of it: this is Henry James's way, and though the method could scarcely be more devious and roundabout, always refusing the short cut, yet by these very qualities and precautions it finally produces the most direct impression, for the reader has seen.

Lubbock discusses other James novels in this crucial book, but the above quotations can stand as an example of the whole new dimension of objectivity, sophistication, and analytic awareness that he brought to bear on the work of Henry James.

In I925 Van Wyck Brooks published The Pilgrimage of Henry James, which proposed a reading of James's whole career as a writer which was to prove very influential. Brooks conceded the brilliance of James's early work, calling him 'the first [American] to present the plight of the highly personalized human being in the primitive community'. But then James made the fatal mistake of cutting himself off from his native land and the later work declines because he is not at home in the culture where he lives.

The caution, the ceremoniousness, the baffled curiosity, the nervousness and constant self-communion, the fear of committing himself-these traits of the self-conscious guest in the house where he had never been at 
home had fashioned with time the texture of his personality. They had infected the creatures of his fancy, they had fixed the character of his imaginative world; and behind his novels, those formidable projections of a geometrical intellect, were to be discerned now the confused reveries of an invalid child.

And in one resounding sentence Brooks nailed down the failings of the last three novels (as he saw them). 'Magnificent pretensions, petty performances!-the fruits of an irresponsible imagination, of a deranged sense of values, of a mind working in a void, uncorrected by any clear consciousness of human cause and effect.' Just as expatriate American writers such as Pound, Eliot and Gertrude Stein respected James, Brooks made James a symbol of all the dangers of expatriation. Looking back on this important book in a later essay Brooks wrote:

And as so many novelists of our own 'twenties lost their substance and grasp of life, it struck me that the case of James was really a symbol - I mean those novelists who had grown up in the so-called expatriate religion of art with a feeling that native lands are not important. Judging by these later cases, it seemed to me disastrous for the novelist to lose his natural connection with an inherited world that is deeply his own, when, ceasing to be 'in the pedigree' of his own country, he is no longer an expression of the communal life.'I

Brooks's insistence that the writer should have a sense of his own society, the conscience of his community, prefigures the sort of criticism which was to become increasingly common in the I930s. And his verdict on the subjective derangement and perversity and loss of human centrality in the last three great novels has been echoed many times since - it is, for instance, essentially the verdict given by F. R. Leavis in The Great Tradition (1948).

Brooks had made a strong case against James, but it did not go unanswered. In a long review of The Pilgrimage Edmund Wilson made some very proper qualifying comments on the justness of Brooks's treatment of James. ${ }^{2}$ Wilson indeed admits that 'Mr Brooks has made a contribution of permanent value toward the criticism of Henry James'. But he immediately makes the point that ' $\mathrm{Mr}$ Brooks has completely

I 'The Pilgrimage', in Days of the Phoenix (New York and London, 1957).

2 'The Pilgrimage of Henry James', in New Republic, xuII (6 May 1925) 283-6; reprinted in The Shores of Light (New York, 1925; reprinted London, 1952). 
subordinated Henry James the artist to Henry James the social symbol. . . . It is precisely because Mr Brooks's interest is all social and never moral that he has missed the point of James's art.' That point, as Edmund Wilson presents it, is that James is one of those artists who is basically interested, not in this or that set of social conditions, but in universal 'conflicts of moral character'. As he says, in some respects James's art improved: in the later works 'the leaning toward melodrama that allowed James in his earlier novels to play virtuous Americans off against scoundrelly Europeans has almost entirely disappeared'. In the late works we do not find any simple schematisation of characters: 'it is simply a struggle between different kinds of people with different kinds of needs'. Wilson denies that James became more worldly, more decadent as he grew older. 'On the contrary, James, in his later works, is just as much concerned with moral problems, and he is able to see all around them as he has not been able to do before.' And in warming to his defence of James (not without making his own qualifying judgements) Wilson makes one especially pertinent remark about what he considers to be the basic theme in James - the lasting conflict between the selfish and the selfless, the worldly and the moral: 'and in this tendency to oppose the idea of a good conscience to the idea of doing what one likes - wearing, as it does so often in James, the aspect of American versus European - there is evidently a Puritan survival'. With characteristic perspicacity Wilson could see that in many ways James was a profoundly American novelist, but it was left to later critics and scholars to explore and discuss in just what ways James's writing reveals the work of an essentially American imagination. We have now become more accustomed to the apparent paradox that a writer may discover more about his own culture by leaving it.

Touching on this paradox, Harry Levin can write in a recent article: 'James demonstrated, as Flaubert had done and Joyce would do, that retirement can be the most serious commitment.'

E. M. Forster's Aspects of the Novel, another notable book on the novel, appeared in 1927. In underlining the importance of Lubbock's The Craft of Fiction he helped to secure for it some of the deserved respect and attention which, initially, it did not receive. 'Those who follow him', wrote Forster of Lubbock, 'will lay a sure foundation for the aesthetics of fiction.' However, Forster himself preferred not to follow him, and his chapter on The Ambassadors criticised James for sacrificing life in the interests of aesthetic form. 
The beauty that suffuses The Ambassadors is the reward due to a fine artist for hard work. James knew exactly what he wanted, he pursued the narrow path of aesthetic duty, and success to the full extent of his possibilities has crowned him. . . . But at what sacrifice! . . . He has, in the first place, a very short list of characters. ... In the second place, the characters, besides being few in number, are constructed on very stingy lines. They are incapable of fun, of rapid motion, of carnality, and of nine-tenths of heroism. Their clothes will not take off, the diseases that ravage them are anonymous, like the sources of their income, their servants are noiseless or resemble themselves, no social explanation of the world we know is possible for them, for there are no stupid people in their world, no barriers of language, and no poor. Even their sensations are limited. They can land in Europe and look at works of art and at each other, but that is all. Maimed creatures can alone breathe in Henry James's pages - maimed yet specialized.

Forster sees James as having 'pruned off' all the wantonness and waywardness and deep complexities of people and society which would not fit into his predetermined, aesthetically satisfying pattern. It is a serious accusation, and similar charges against James's work have been voiced by eminent men as different as William James and André Gide and can still be heard today, particularly from those who take Tolstoy to be the ideal type of novelist.

A rather significant spokesman for such a point of view was Vernon Louis Parrington, and it is unusually apt that his disparaging remarks about James should have been published in 1930 - a suitable preface, as it were, to the decade in which James's reputation slumped to its lowest point. Parrington's important book was called The Beginnings of Critical Realism in America (1860-1920), and he starts his attack on James by citing a comment by Pelham Edgar from his book Henry James, Man and Author (1927). Edgar was one of those critics who held up James as a supreme representative of 'civilisation'. 'Civilisation at its highest pitch was the master passion of his mind, and his preoccupation with the international aspects of character and custom issued from the conviction that the rawness and rudeness of a young country were not incapable of cure by contact with more developed forms.' This condescending attitude towards America infuriated Parrington, and his subsequent comments on James read like a more severe extension of Brooks's objections.

He suffered the common fate of the déraciné; wandering between worlds, he found a home nowhere. It is not well for the artist to turn cosmopolitan, 
for the flavor of the fruit comes from the soil and sunshine of its native fields. ... Did any other professed realist ever remain so persistently aloof from the homely realities of life? From the external world of action he withdrew to the inner world of questioning and probing; yet even in his subtle psychological inquiries he remained shut up within his own skull-pan. His characters are only projections of his brooding fancy, externalizations of hypothetical subtleties. He was concerned only with nuances . . . how unlike he is to Sherwood Anderson, an authentic product of American consciousness!

It is rather crude stuff after Lubbock's criticism, and the sweeping generalised indictments reveal a very imperfect reading of James's actual novels, if not a radical ignorance of them. But the final reference to Anderson - a comparison obviously intended to be to James's disadvantage-makes clear the motive behind the animus. After a decade of expatriates the feeling was growing that American writers should turn their attention to the 'homely realities' and 'sprawling energy' of American life - to the physical local details of the many places in America which were perhaps without any traditional civilisation and culture, but where people's sufferings were no less real for being comparatively inarticulate. Needless to say the varying degrees of Marxism produced in different writers by the economic disasters of the I930s encouraged this feeling about the responsibilities of the American writer. Speaking very generally, if the key American writers of the I920s were Hemingway and Scott Fitzgerald and, in a different way, T. S. Eliot and Ezra Pound, then we can see the r930s as the decade of Dos Passos, John Steinbeck, James Farrell and, in a different way, William Faulkner. In such a decade it is not surprising that interest turned away from Henry James, and that, if his reputation did not exactly disappear, his books were mainly unread. We find an intelligent critic, William Troy, writing in I93 I that 'James is in immediate need of some sort of reinstatement at the moment'. 'Troy makes an eloquent case for the relevance of James for the young contemporary writer: he explains how James, like any other great artist, worked to impose some sort of order on the 'splendid waste' of life (James's own phrase), and he insists that James did not turn away from the values of life in order to cultivate the values of art. Troy ends his essay trying to persuade contemporary writers that James still has much to give them. "What they can learn from him

1 'Henry James and Young Writers', in Bookman, Lxxm (June I93I) 35I-8. 
is the deepest meaning of the phrase "the integrity of the artist". $\mathrm{He}$ can show them to what an essential degree the artist is dependent on something anterior to himself in life; how the truest values of art are never to be dissociated from the most potent values of the world about him.' It was fairly said, but it would be some years before James was in any way 'reinstated'.

This is not to say that he received no significant attention during the I930s: on the contrary, a number of important articles were published during that decade which no survey of James criticism can ignore. In 193 I Constance Rourke, in a book of tremendous importance for the study of American literature-American Humor-devoted a long and brilliant chapter to James and his book The American. Dismissing the accusations that James was 'a troubled evasionist without a country', she established with emphatic directness one of James's major purposes. 'James was bent upon a purpose that had absorbed many American fabulists, that of drawing the large, the generic, American character.' She pointed out that his 'gallery of characters' provided 'a legible critique of the American character for those who care to read it', and she showed how very accurately his work reflects the changes that came over American society in the later nineteenth century. Miss Rourke was one of the first critics to expand a little on the distinctly American aspects of James's genius.

$\mathrm{He}$ was grounded in the Yankee fable; his basic apprehension of the American character was that which had been drawn there . . . he came closer than any of the earlier American writers to that introspective analysis which had belonged to the Puritan, closer even than Hawthorne. . . . Whether or not James was subject to some untraceable Puritan influence, whether he touched popular sources, whether perhaps he gained greatly from the initial experiments of Hawthorne and Poe, his novels vastly amplified this new subject of the mind lying submerged beneath the scope of circumstance, which had long engaged the American imagination.

Miss Rourke makes an interesting comparison between Mark Twain's Innocents Abroad and James's The American - just as, later, Edmund Wilson would suggest a comparison between $A$ Connecticut Yankee in King Arthur's Court and The Sense of the Past-and notes how unthinkable it would be for an English or French writer to write books simply called The Englishman or The Frenchman; and she discusses what James added to the generic portrait of the American in his first major novel - "in the spelling of the old fable the outcome 
had changed from triumph to defeat. Defeat had become at last an essential part of the national portraiture.' Noting that 'triumph had hitherto been the appointed destiny in American portraiture, except for vagabonds and common adventurers', she shows how 'again and again James pictured this low-keyed humor of defeat'. Her essaystressed that James added depth and subtlety to the portrait of the generic American. 'He showed that the American was in truth what the belligerent Yankee had always declared him to be, a wholly alien, disparate, even a new character.' And she also noted the predominantly unsatisfying or pathetic fate suffered by James's venturing Americans. 'For the most part emotion in these Americans in his wide gallery is frustrated, buried, or lost. Instead, renunciation, tenderness, pity, are likely to be dominant among them.' Miss Rourke finished her essay by noting that subsequent American writers had been influenced only by James's subject - not by his technique. 'In later years other American writers have followed him in using the international scene; yet his other great achievement, that of portraying the inner mind, cannot be said to have given any notable impetus to the American novel.' She notes that the 'portrayal of the inner consciousness' has been developed mainly by European writers-Proust, Joyce, Virginia Woolf and Dorothy Richardson. But Miss Rourke's essay was more important for stressing James's American origins than his European influence.

It was in the mid-I930s that Edmund Wilson wrote the long study called 'The Ambiguity of Henry James', ' which has since become famous if only because it precipitated a prolonged argument over the meaning of The Turn of the Screw which is still alive some thirty years later. Bringing an overtly Freudian approach to bear on James for (I think) the first time, Wilson sees the figure of the governess in The Turn of the Screw as a study in hysteria and morbid hallucinations consequent upon deep sexual repression and frustration. 'We see now that it is simply a variation on one of James's familiar themes: the frustrated Anglo-Saxon spinster', and Wilson develops his anatomy of the Jamesian world by pointing out that not only are most of his female characters either 'emotionally perverted' or 'emotionally apathetic', but the men also seldom achieve normal passional fulfilment. 'James's men are not precisely neurotic; but they are the masculine counterparts of his women. They have a way of missing out on 
emotional experience, either through timidity or caution or through heroic renunciation.' And having found The Sacred Fount to contain 'the conception of a man shut out from love and doomed to barren speculation on human relations', Wilson applies his psychological insights about James's work to James himself. 'He seems to be dramatizing the frustrations of his own life without quite being willing to confess it, without always admitting it to himself.' Wilson then develops an interesting contrast between James's attitude to his young protagonists, and Flaubert's: 'whereas in James the young man is made wondering and wistful and is likely to turn out a pitiful victim, in Flaubert he is made to look a fool and is as ready to double-cross these other people who seem to him so inferior to himself as they are to double-cross him'. James is incapable of Flaubert's remorseless and bitter irony. But Wilson goes on to point out that there is an important difference between the two writers: 'there was another kind of modern society which Flaubert did not know and which Henry James did know. Henry James was that anomalous thing, an American. . . . The American in Henry James insistently asserts himself against Europe.' Wilson notes that in the later novels 'it is always the Americans who have the better of it from the moral point of view'. And he paraphrases what seems to him James's final assessment of his Americans. 'Yes: there was a beauty and there was also a power in the goodness of these naïve and open people, which had not existed for Flaubert and his group. It is something different and new which does not fit into the formulas of Europe.' Again we notice that it is the American Henry James that Wilson stresses. And despite his apparently severe psychological comments on James's particular relationship to life, Wilson ends this long essay with the highest praise. 'For Henry James is a great artist, in spite of everything. His deficiencies are obvious enough. He was certainly rather short on invention; and he tended to hold life at arm's length.' (Wilson makes the interesting suggestion that his 'censure of Tolstoy for his failure to select is a defensive reflex action on Henry James's part for his own failure to fill in his picture'.) But Wilson goes on to say that 'the objects and beings at the end of James's arm, or rather, at the end of his antennae, are grasped with an astonishing firmness, gauged with a marvellous intelligence', and he ends his essay by equating James with the greatest writers.

His work is incomplete as his experience was; but it is in no respect second-rate, and he can be judged only in the company of the greatest. 
My argument has not given me an occasion to call attention to the classical equanimity, the classical combination of realism with harmony - I have tried to describe them in writing about Pushkin - which have been so rare in American and in English literature alike and of which James is one of the only examples.

Hitherto, roughly speaking, we have seen James appreciated for his highly cultured intelligence; because he is on the side of true civilisation; and on account of his masterly technical innovations. We have seen him praised both as one of the great explorers and fabulists of the American character and also as one of the first great modern novelists of the world within, the first to dramatise the inward effort and strain of the unique - and lonely - perceiving consciousness as it seeks to understand and negotiate new and problematical worlds. Now, around the mid-1930s, another James was emphasised: the James whose work was full of intimations of horrible decadence, of imminent social disorder and chaos, perhaps even war. Instead of the emphasis being on James's refined sense of civilisation, it now falls on James's profound vision of evil. I think it is worth mentioning the comments of three writers to illustrate this new emphasis in James criticism. In 1934 the American critic Newton Arvin published an article in Hound \& Horn called 'Henry James and the Almighty Dollar'.' This was one of the earliest attempts to portray James as a penetrating critic of the society of his own times. Arvin admits that James seems somewhat reluctant to embark on any direct indictment of his age, but he points to "The Princess Casamassima, with its hints at the decadence of the privileged classes, its evocation of the dreariness and hopelessness of life in the London slums, its intentionally vague intimations of retributive movements from below', and goes on to claim that James's 'penetrating ethical insight' served him as well as any detailed historical or sociological knowledge. The point he brings forward is this: 'that Henry James's world, especially the world of his later fiction, is far from being a pretty one; that, on the contrary, it is morally as ugly a world as any in the English novel, up to that point, and that a tiny handful of decent people wander through it, bravely or timidly as the case may be, like men astray in a land of condors and boas'. He singles out the 'gross preoccupation with money' which marks James's characters and says that 'James's scene is one in which greed plays something like the same role as snobbishness in Thackeray's scene or sentimentality in

I vII (April-June 1934). 
Meredith's'. Henry James 'became in his old age the chronicler of a festering society' and lays bare 'a world obsessed by the nervous craving for acquisition and haunted by fear of penury'. This is how Arvin summed up: 'It was a greedy society in the midst of which James found himself living; and, though all the conditions of that greediness were never made clear to him - though he failed to criticize it from a more significant angle than that of a refined individualism - he was too honest, too responsible, too scrupulous a writer to white-wash society as he found it.'

Also in 1934 Stephen Spender published his important book The Destructive Element. This contained an extremely penetrating analysis of the world of The Golden Bowl and, in particular, Spender emphasised not only that it was a predominantly 'dead' world, but also that it was pervaded by a 'feeling of horror that is entirely modern'. He cites some of the more vivid images of pain, torture, suffering and dread that occur in the book and comments:

When one considers these examples, one begins to feel certain that beneath the stylistic surface, the portentous snobbery, the golden display of James's work, there lurk forms of violence and chaos. His technical mastery has the perfection of frightful balance and frightful tension: beneath the stretched-out compositions there are abysses of despair and disbelief: Ulysses and The Waste Land.

What after all do these images of suffocation, of broken necks, of wailing suggest but a collection of photographs of the dead and wounded during the Great War? We remember his phrase, made in I9I5: 'to have to take it all now for what the treacherous years were all the while making for and meaning, is too tragic for words'.

Having discussed the many felicities in James's art, Spender, like Arvin, emphasises the social criticism implicit in his work - 'his account of our society makes, in effect, an indictment as fierce as that of Baudelaire'. Spender sees a contradiction in James's attitude, for if James loathed the corruption of his society he also relied on the freedom and independence which that society secured for him. 'He saw through the political and social life of his time, but he cherished the privilege which enabled him to see through it.' Perhaps Spender mainly reveals his own political attitude at the time when he mentions Joyce and Wyndham Lewis along with Henry James and says 'the key to the subjectivism of all these writers is an intense dissatisfaction with modern political institutions'. But his picture of James as a writer 
who was intensely aware of the horrors and abysses in modern society would help to make James seem more relevant to a generation who would have had little time for an artist presented as a sort of Pateresque devotee of 'the beautiful'.

In 1936 Graham Greene added his powerful contribution to the conception of James as a man more preoccupied with a vision of evil than with the refinements of the gentcel. In his essay 'The Private Universe' $\mathrm{r}$ he starts by paying tribute to Percy Lubbock for having described the technical achievement of James and says that he now wants to 'try to track the instinctive, the poetic writer back to the source of bis fantasies'. He finds the key to James in one of the last things he wrote. 'I think we may take the sentence in the scenario of The Ivory Tower, in which James speaks of "the black and merciless things that are behind great possession" as an expression of the ruling fantasy that drove him to write: a sense of evil religious in its intensity'. Like Spender, Greene sees some sort of intuitive connection between the world of James's late novels and the First World War - 'they are complete anarchists, these late Jamesian characters, they form the immoral background for that extraordinary period of haphazard violence which anticipated the First World War'; but he sees James's preoccupation as one which transcends modern politics. He notes that both James's father and brother had had visionary experiences of utter evil and horror and, having described these visions as reported in their writings, he maintains that they 'are a more important background to Henry James's novels than Grosvenor House and late Victorian society'. 'It is true that the moral anarchy of the age gave him his material, but he would not have treated it with such intensity if it had not corresponded with his private fantasy. They were materialists, his characters, but you cannot read far in Henry James's novels without realising that their creator was not a materialist. If ever a man's imagination was clouded by the pit, it was James's.' Greene understands the emphasis on James as a social critic but insists that

the Marxists, just as much as the older critics, are dwelling on marginalia. ... His lot and his experience happened to lie among the great possessions, but 'the black and merciless things' were no more intrinsically part of a capitalist than of a socialist system: they belonged to human nature. They amounted really to this: an egotism so complete that you

I Reprinted in The Lost Childhood and other essays (London and New York, 195I). 
could believe that something inhuman, supernatural, was working through the poor devils it had chosen.

Just as we can see Spender revealing his own preoccupations when he writes about James, so we note that Greene emphasises that aspect of James which is most sympathetic to his own view of the universe. Yet it is the mark of a great writer than he can appeal to many different imaginations and many different visions of life: it testifies to the universality of his relevance; the range and variety of experience he has touched on; the encompassing humanity of his awareness. Where Edmund Wilson chooses to stress a balance between realism and harmony comparable with Pushkin's, and Spender emphasises a modern awareness of society analogous to Joyce's, Greene fastens on the pervading pity in James's work, which he compares, in what is perhaps the highest claim ever made for James, to that of Shakespeare: "it is in the final justness of his pity, the completeness of an analysis which enabled him to pity the most shabby, the most corrupt, of his human actors, that he ranks with the greatest of creative writers. He is as solitary in the history of the novel as Shakespeare in the history of poetry.'

That would seem to provide a good point on which to conclude this brief survey of the changing critical attitude to James up to the Second World War. And, in fact, after these important articles of the mid-r93os not very much was heard about James for a while. Indeed the PMLA bibliography of scholarly work, which is printed every year, has no entries under the name of James for the years from 1933 to 1937 (inclusive). A provocative article on James by Yvor Winters appeared in 1938,1 and a well-known appraisal of his work by L. C. Knights appeared in 1939 (it was reprinted in Explorations); then 1940 again seems to be a blank year. But throughout the 1940s, with some fluctuations, interest in James increased steadily (to use the PMLA bibliography as a rough guide once more - five cntries for I94I, twenty-five for 1949). Faced by this escalation of interest it is perhaps arbitrary to single out any one piece of writing as being particularly influential or significant. Yet one publishing event does seem to mark the real beginning of the modern interest in James. In the autumn of James's centenary year, 1943, Robert Penn Warren edited a number of the Kenyon Review which was entirely devoted to James and

I Reprinted in In Defence of Reason (New York, I947). 
contained serious, often brilliant, articles by such distinguished critics as R. P. Blackmur, Francis Fergusson, Austin Warren, Jacques Barzun and David Daiches. This formidable group of essays certainly consolidated James's reputation and probably did much to enhance it. Also in 1943 an essay by another famous critic, Philip Rahv, ${ }^{1}$ seems to look both to the past and the imminent future of James criticism. Rahv notes that, at the time, James 'is at once the most and least appreciated figure in American writing', and he gives examples of how James is misinterpreted, particularly in America. On the other hand the intelligence and insight of his own comments on James is indicative of the understanding and respectful treatment that James was to receive at the hands of the leading American critics of the I940s and I950s. Perhaps typically of that generation he stressed the 'doubleness' of James.

His characteristic themes all express this doubleness. The 'great world' is corrupt, yet it represents an irresistible goal. Innocence points to all the wanted things one has been deprived of, yet it is profound in its good faith and not to be tampered with without loss. History and culture are the supreme ideal, but why not make of them a strictly private possession? Europe is romance and reality and civilization, but the spirit resides in America. James never faltered in the maze of these contraries; he knew how to take hold of them creatively and weave them into the web of his art.

Clearly there was some connection between the war and the sudden access of interest in James on a wide scale, though to speculate here would be out of place (I have included one essay from 1943 by William Troy which suggests some reasons). Pretty certainly the Hitler-Stalin pact discredited all kinds of Marxist criticism and thus released James for less doctrinaire handling, but whether it was the 'darkness' or the 'civilisation' in Henry James's work which appealed more when civilisation itself was enduring its darkest hours must have depended on the individual reader. The fact we can be sure of is that the number of people reading James increased enormously and continued to increase after the war. Since 1943 the books, dissertations and articles on James have continued to appear in almost unmanageable numbers (the PMLA bibliographies for 1964 and 1965 both have over sixty entries under Henry James). Any summary of the critical work on

I 'Attitudes toward Henry James', in New Republic, is Feb. I943. 
James since the war is well beyond the scope of this essay. Every aspect of James has been subjected to numerous approaches. You can find different studies of his themes, philosophy, moral vision, metaphysics, psychological theories; of the different periods of his own life; of the imagery, symbolism, syntax, allegory, fantasy and emblems in his work; of his various narrative and dramatic techniques; of his reactions to America, England, Italy, etc; of his relation to various writers, American, European and English, and to various members of his own family; of the manifold sources for his novels and stories, ranging from the ancient Greeks to his French contemporaries; of his revealing revisions of his earlier work, etc. There is no point in continuing a list which could be extended indefinitely. Inevitably one may sometimes wonder if so much is necessary or desirable. Will not the critics and scholars bury James under their amplifications, explanations, speculations, whatever?

A major James scholar, Oscar Cargill, writing in the early 1960 s said: "Working through the very great mass of commentary on James's fiction, I have been struck by a curious deficiency - nobody apparently reads anybody else - there is no accumulated wisdom, no "body" of appreciation.' I It is a just observation; and, of course, unnecessary repetition there has been. But it is possible to see this phenomenon as testifying to the stature of James as an artist. The truly great writers are inexhaustible; they are susceptible to a plurality of interpretations because their imaginative vision has comprehended and preserved so much potential human experience. When the critics and scholars produce new essays and books about Shakespeare year after year, they are not struggling for some definitive solution: they are preserving a heritage we can ill afford to lose; they are, by their ongoing discussions, maintaining a vital contact with one of the most profound imaginations that the human race has produced. James is no Shakespeare, but he is a great writer - one whom every age will appropriate for itself in its own way. The work of a great writer is so much deeper and wider and more inclusive than the mind of any single critic that no one man can, or should, hope to dredge up all the richness and mysteries which the writer has, miraculously, caught and contained in his work. It is worth remembering the dying writer in James's story 'The Middle Years': 'He sat and stared at the sea, which appeared all surface and twinkle, far shallower than the spirit of man.

I The Novels of Henry James (New York, I961) p. xii. 
It was the abyss of human illusion that was the real, the tideless deep.' Only the greatest minds, the greatest imaginations can comprehend something of that 'tideless deep' which is the 'spirit of man' and then only fitfully. As the writer in the story makes clear in his dying words: "We work in the dark - we do what we can - we give what we have. Our doubt is our passion and our passion is our task. The rest is the madness of art.' It is only an apparent paradox that the sanity of society is in a crucial way dependent on 'the madness of art'. But the art cannot be fully explained; it is simply there to be experienced and appreciated according to our abilities and susceptibilities. As James said, to criticise properly is 'to appropriate, to take intellectual possession, to establish in fine a relation with the criticised thing and make it one's own'. The strange promiscuity of a great work of art is such that it can be appropriated, possessed, made over countless times in countless ways, and yet be still open to another relationship with some new inquiring mind. I would like to think that the Criticism, Discrimination and Appreciation of the last twenty years would have seemed somewhat less infantile to James than that of his own age. But having said that we must guard against any complacency by realising that, with a writer like James, there is and can be no question of anything like a final definitive 'appropriation' of his work. Only endless revisits to an inexhaustible source.

TONY TANNER 


\section{Note on the Principles of Selection}

CONFRONTED by the vast amount of critical material which has accumulated around the work of Henry James, any anthologist has to take some ruthless decisions about what to omit. For the benefit of any intending reader I should perhaps make mine clear from the start, and if possible explain them. First, since there are so many good and valuable articles which have not been made available in book form I took the initial decision not to include any work which had, to my knowledge, appeared in a book. I am well aware that I thereby debarred much of the most distinguished work on James, but the books are readily available, and anyone at all interested will want to read them in toto. To select extracts and chapters from various books to make yet another book seemed in this particular case to be unjustifiable repetition. Instead I have added a bibliography which attempts to cover most of the important books on James.

Secondly, I have deliberately avoided including many excellent articles which have been reprinted, included in anthologies and referred to and cited so often that any anthology which offered them to the public once more, albeit in a new context and relationship, would become immediately redundant. Thus, for example, there are no essays by Joseph Conrad, T. S. Eliot, Edmund Wilson, Lionel Trilling, Alfred Kazin, Philip Rahv, Morton Zabel, Richard Blackmur, Stephen Spender, F. O. Matthiessen, Jacques Barzun, Leon Edel, F. W. Dupee, Richard Poirier, Irving Howe and other distinguished writers and critics whose names are rightfully connected with the history of James criticism. I contend that the very distinction of many of the essays by these eminent men has rendered them too well known to require further republication (some I have summarised in my introductory essay).

Thirdly, I have limited my selection to criticism written since 1943. There is enough admirable material to justify this concentration, and I 
have tried to give a fairly comprehensive picture of James criticism before that date in my introductory essay.

The essays I have chosen, then, are neither particularly famous, nor are they selections from books. But they seem to me representative of the different kinds of intelligence, patient research, imaginative interpretation and sensitive study which have been exercised in the field of James studies in the last twenty-five years or so. And my hope is that this anthology might serve two functions. For those already interested in James it offers itself as a supplement to the better-known James criticism, which they probably possess or know. It seeks to bring together essays, often rather hard to find (for instance, from scholarly American journals not readily available except in the largest libraries), which make a definite contribution to our understanding, appreciation and knowledge of James's work - a contribution not already covered by the available books on James. On the other hand, for those who are just starting to read James, it will serve as a helpful introduction and a continual aid. There are some general essays which contribute to our comprehension of James's fictional world and his whole conception of the writer; then there are essays on different aspects of most of the major novels. It is doubtless too much to hope to please all of the people even some of the time; nonetheless my hope is that anybody with any interest in James will find this collection in some degree helpful, informative, stimulating and enriching. If nothing else, let it stand as an appreciative tribute to the vital attraction which the work of Henry James continues to have for our own age. 


\section{Chronology}

\begin{tabular}{|c|c|}
\hline I 843 & Born on Is April in New York. \\
\hline I $855-8$ & $\begin{array}{l}\text { Goes to schools in Geneva, London and Paris before } \\
\text { returning to live in Newport, Rhode Island. }\end{array}$ \\
\hline I 860 & $\begin{array}{l}\text { While at school at Newport, sustains the strange injury to } \\
\text { his back that prevented him from taking part in the Civil } \\
\text { War. }\end{array}$ \\
\hline 862 & Attends Harvard Law School for one year. \\
\hline 864 & $\begin{array}{l}\text { His family settles in Cambridge, Massachusetts. James has } \\
\text { his first story and reviews published. }\end{array}$ \\
\hline I $869-70$ & $\begin{array}{l}\text { Travels in England, France and Italy. While he is abroad, } \\
\text { his young cousin Minny Temple dies. }\end{array}$ \\
\hline I 870 & Publishes his first novel, Watch and Ward. \\
\hline I $872-4$ & Again in Europe, where he begins Roderick Hudson. \\
\hline I874-5 & $\begin{array}{l}\text { Roderick Hudson published ( } 1875 \text { ), as well as a book of } \\
\text { stories and a book of travel sketches. James in New York } \\
\text { doing literary journalism. }\end{array}$ \\
\hline I875-6 & $\begin{array}{l}\text { Spends a year in Paris, where he meets eminent writers, } \\
\text { such as Turgenev, Flaubert and Zola. Writes The American } \\
\text { (published I877). }\end{array}$ \\
\hline $876-7$ & Settles in London. \\
\hline 878 & The publication of Daisy Miller brings James some fame. \\
\hline I $879-8$ & $\begin{array}{l}\text { Publishes The Europeans (I878), Washington Square (I880), } \\
\text { Confidence (I880) and The Portrait of a Lady (I88I). }\end{array}$ \\
\hline I $882-3$ & His parents die. \\
\hline I 886 & Publishes The Bostonians and The Princess Casamassima. \\
\hline I 887 & Another visit to Italy. \\
\hline I $888-9$ & $\begin{array}{l}\text { Publishes The Reverberator (1888) and The Tragic Muse } \\
\text { (1890). }\end{array}$ \\
\hline-5 & $\begin{array}{l}\text { Tries to write for the theatre, finally abandoning the } \\
\text { attempt after being booed at the first night of Guy }\end{array}$ \\
\hline
\end{tabular}


1897-8 The Spoils of Poynton and What Maisie Knew (1897). Moves to Lamb House, in Rye, Sussex.

I899-1904 Publishes The Awkward Age (1899), The Sacred Fount (1901), The Wings of the Dove (1902), The Ambassadors (1903), William Wetmore Story and his Friends (1903) and The Golden Bowl.(1904).

I905-10 Revisits America after an absence of twenty years. He writes The American Scene (1907) and then edits the twentyfour volume New York Edition of his works.

I910 His brother, William, dies.

1913-I4 Writes his autobiographical volumes $A$ Small Boy and Others (I9I3) and Notes of $a$ Son and Brother (I9I4).

I9Is Becomes a British subject.

I9I6 Dies on 28 February. He leaves two unfinished novels, The Ivory Tower and The Sense of the Past, and a third autobiographical volume, The Middle Years, all three published in 1917 . 